\title{
ОСОБЛИВОСТІ ДІАГНОСТИКИ КОМУНІКАТИВНОӦ ДІЯЛЬНОСТІ УЧНІВ ІЗ ЗАТРИМКОЮ ПСИХІЧНОГО РОЗВИТКУ
}

\author{
Ольга Бабяк, Інститут спеціальної педагогіки НАПН України, м. Київ, Україна
}

На основі теоретичних та емпіричних методів дослідження було визначено особливості функціонування мотиваційного, операційного та когнітивного компонентів комунікативної діяльності. Мотиваційний компонент дає змогу виявити особистісні та соціальні потреби, які визначають комунікативну активність особистості, операційний - комунікативну поведінку, яка відповідає нормам поведінки у суспільстві і здійснюється за допомогою саморегуляції; когнітивний — комунікативну компетентність та культуру, які визначаються комунікативними якостями, знаннями, вміннями, навичками, здібностями.

Результати дослідження дають підстави стверджувати, що в учнів із ЗПР комунікативна діяльність сформована недостатньо, а саме: переважання домінантних фрорм поведінки 3 негативним ставленням до однолітка зі спільної діяльності, що характеризується низькою потребою в спілкуванні, афективними проявами поведінки, конфрліктністю, обмеженістю комунікативних можливостей; високим рівнем конфрліктності, підвищеним рівнем агресивності, що виражається в афективних, розгальмованих фрормах відхилень в емоційно-вольовій сфері; низьким рівнем взаємодій з оточуючими, низьким рівнем розвитку потреби в спілкуванні з навколишніми людьми, недосконалістю комунікативних засобів здійснення контактів. Низький стан сформованості компонентів комунікативної діяльності призводить до значних труднощів, що виникають під час взаємодії один 3 одним, а це впливає на подальшу соціалізацію та інтеграцію у соціум.

Ключові слова: затримка психічного розвитку, комунікативна діяльність, шкільний вік, компоненти комунікативної діяльності, ускладнене спілкування, взаємодія, міжособистісні контакти.

Ольга Бабяк, Институт специальной педагогики АПН Украины, г. Киев, Украина Особенности диагностики коммуникативной деятельности школьников с задержкой психического развития

На основе теоретических и эмпирических методов исследования были определены особенности функционирования мотивационного, операционного и когнитивного компонентов коммуникативной деятельности. Мотивационный компонент позволяет выявить личностные и социальные потребности, которые определяют коммуникативную активность личности, операционный - коммуникативное поведение, соответствующей 
нормам поведения в обществе и осуществляется с помощью саморегуляции; когнитивный коммуникативную компетентность и культуру, которые определяются коммуникативными качествами, знаниями, умениями, навыками, способностями.

Результаты исследования дают основания утверждать, что у школьников с 3ПР коммуникативная деятельность ссрормирована недостаточно, а именно: преобладание доминантных фрорм поведения с негативным отношением к сверстнику по совместной деятельности, характеризующееся низкой потребностью в общении, афффективными проявлениями поведения, конфликтностью, ограниченностью коммуникативных возможностей; высоким уровнем конфрликтности, повышенным уровнем агрессивности, что выражается в аффрективных, расторможенных формах отклонений в эмоциональноволевой сфере; низким уровнем взаимодействия с окружающими, низким уровнем развития потребности в общении с окружающими людьми, несовершенством коммуникативных средств осуществления контактов. Низкое состояние сфрормированности компонентов коммуникативной деятельности приводит к значительным трудностям, которые возникают при взаимодействии друг с другом, а это в свою очередь влияет на дальнейшую социализацию и интеграцию в социум.

Ключевые слова: задержка психического развития, коммуникативная деятельность, школьный возраст, компоненты коммуникативной деятельности, затруднено общение, взаимодействие, межличностные контакты.

Olga Babiak, Institute of Special Pedagogy of the Academy of Pedagogical Sciences of Ukraine, Kiev, Ukraine

Features of diagnosis of communicative activity of schoolchildren with intellectual disability The article is dedicated to the study of the features of communicative activity of students with a developmental delay, the formation of motivational, operational and cognitive components of communicative activity. An empirical study allowed to determine the degree and qualitative features of the components of communicative activity in children with intellectual disabilities. On the basis of theoretical and empirical research methods, features of the functioning of the motivational, operational and cognitive components of communicative activity were determined. The motivational component allows to identify the personal and social needs that determine the communicative activity of the individual, the operational - communicative behavior that meets the standards of conduct in society and is carried out through self-regulation; cognitive communicative competence and culture, which are determined by communicative qualities, knowledge, abilities, skills, competences.

The results of the study provide grounds to assert that in schoolchildren with developmental delay students lack sufficient formation of the communicative activity, namely: the predominance of dominant forms of behavior with negative attitude towards peers from a joint activity characterized by a low need for communication, affective manifestations of behavior, tendency to provoke conflict, limited communicative possibilities; high level of conflict, increased level of aggressiveness, expressed in affective, frustrated forms of deviations in the emotional-volitional sphere; low level of interactions with others, low level of development of the need for communication with the surrounding people, imperfect communicative means of making contacts. The low state of the formation of components of communicative activity leads to significant difficulties that arise when interacting 
with one another, which in turn affects further socialization and integration into society. Keywords: intellectual disability; communicative activity; school age; components of communicative activity; complicated communication; interaction; interpersonal contacts.

$\Pi$ сихолого-педагогічні особливості комунікативної діяльності дітей із затримкою психічного розвитку (ЗПР) є предметом дослідження Д. Альраххаля, Т. Артемьєвої, Н. Афанасьєвої, О. Бабяк, Н. Білопольської, Е. Вінникової, Г. Грібанової, Г. Коропової, І. Омельченко, В. Пермякової, К. Слєпович, Р. Тригер та ін.

Дослідники відзначають низку труднощів комунікативної діяльності, а саме: спілкування відбувається в невеликих ендогенних групах з дітьми молодшого шкільного віку і має швидкоплинний характер; спілкування відзначається інфантильністю комунікативних зв'язків, які поєднується з підвищеним рівнем тривожності, невпевненістю, низьким рівнем домагань, підвищеною навіюваністю, пасивністю, слабким усвідомленням свого «Я». (А. Бодальов, Л. Гозман, Р. Тригер).

Комунікативність характеризується слабкою орієнтованістю на однолітків, конфліктністю, агресивністю, сильною вираженістю потреби в домінуванні і підлеглості. (Р. Тригер, А. Петровський, Я. Коломенський, В. Кисловська, А. Копилова). Учені наголошують, що структурні, емоційні аспекти комунікативної діяльності і їх формування у дітей із затримкою психічного розвитку менш вивчені.

Окремі дослідження показують, що діти із ЗПР можуть мати високий потенціал соціальної адаптації, за умови створення сприятливих можливостей для іхньої реалізації.

Необхідно відзначити, що наявні технологічні розробки формування комунікативної діяльності орієнтовані на норму в розвитку психіки, а спеціальних технологій з формування комунікативності, орієнтованих на дітей із ЗПР, розроблено недостатньо.

Мета та завдання. Метою статті є висвітлення результатів емпіричного дослідження, яке було спрямоване на виявлення специфіки комунікативної діяльності учнів із затримкою психічного розвитку в групі й давало можливість вивчити особливості функціонування мотиваційних, операційних та когнітивних складових комунікативної діяльності. Для досягнення поставленої мети були поставлені завдання дослідження:

1) здійснити аналіз психологічної літератури з проблеми комунікативної діяльності дітей із ЗПР, особливостей комунікативної взаємодії з однолітками;

2) висвітлити результати емпіричного дослідження особливостей комунікативної діяльності дітей із затримкою психічного розвитку, зокрема мотиваційних, операційних та когнітивних їі складових.

Методи дослідження. Для вирішення поставлених завдань використано комплекс теоретичних та емпіричних методів дослідження. Теоретичні методи - аналіз, синтез, порівняння, систематизація та узагальнення теоретичних та емпіричних результатів дослідження. Емпіричні - передбачали застосування таких методик:

«ОСОБЛИВА ДИТИНА: навчання і виховання», № 1, 2019 
- «Спостереження в навчальній та позанавчальній діяльності»; • «Соціометрія» (адаптована Г. Карповою, Г. Артем'євою);

- «Шкала соціальної компетентності»( Г. Прихожан);

- «Тест ціннісних орієнтацій» (М. Рокича).

На нашу думку, такі діагностичні засоби дають можливість 3'ясувати не тільки особливості комунікативної діяльності учнів, а виявити способи іх взаємодіï, простежити зміст комунікативного функціонування і внутрішньо-особистісні конфлікти і характер соціальних труднощів у дітей з ЗПР. У процесі аналізу обчислення результатів особливу увагу звертали не лише на правильність відповіді, а й на мотивацію дитини, іiі установку.

У дослідженні брали участь учні із затримкою психічного розвитку та учні 3 нормативним розвитком (далі НР), віком 7-10 років. Дослідження у порівняльному плані давало можливість грунтовніше виділити специфічні особливості компонентів комунікативної діяльності у дітей із ЗПР. При цьому виконання діагностичних завдань дітьми з НР слугувало показником вікової норми.

Обираючи для порівняння вікові групи дітей із ЗПР, та з НР ми зважали на те, що у нормі комунікативна діяльність вже сформована в учнів (7 10 років). Нас цікавила вікова динаміка їі розвитку, тому віковою групою були обрані діти 2-4 класів, віком 7-10 років із ЗПР і НР.

Різниця у віці учнів 2-4 класів з нормативним розвитком і із затримкою психічного розвитку, які брали участь в експерименті пояснюється тим, що учні із ЗПР розпочинають навчання в школі на 1-2 роки пізніше від їх однолітків 3 нормальним розвитком через недорозвиток пізнавальної сфери, всіх психічних процесів, що створює патогенну основу для розвитку міжособистісних стосунків дітей цієї категорії. Вивчення особливостей міжособистісних стосунків в учнів із ЗПР здійснювалося трьома етапами, за визначеними критеріями, що дало змогу з'ясувати показники та рівні особливостей поведінкового, афективного та когнітивного компонентів міжособистісних стосунків у дітей із ЗПР.

Результати теоретико-емпіричного дослідження. На основі теоретичного аналізу було визначено компоненти комунікативної діяльності, до яких віднесено: мотиваційний (особистісні та соціальні потреби, які визначають комунікативну активність особистості), операційний (комунікативна поведінка, яка відповідає нормам поведінки у суспільстві і здійснюеться за допомогою саморегуляції), когнітивний (комунікативна компетентність та культура, які визначаються комунікативними якостями, знаннями, уміннями, навичками, здібностями.

Розкрито основні критерії сформованості комунікативної діяльності а саме: взаємодія в спільній діяльності; взаємодія один з одним; встановлення міжособистісніх контактів; міжособистісне спілкування; уміння диференціювати якості людини; уміння адекватно оцінювати себе і розуміти свою соціальну роль в загальній структурі взаємостосунків членів групи; взаємосприймання і взаєморозуміння один одного.

Якісний аналіз емпіричного дослідження компонентів комунікативної діяльності в учнів із ЗПР вказує на низку особливостей. Так, особливостями операційного компонента є: переважання домінантних форм поведінки з негативним 


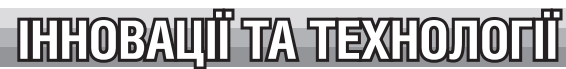

ставленням до однолітка зі спільної діяльності, що характеризується низькою потребою в спілкуванні, афективними проявами поведінки, конфліктністю, обмеженістю комунікативних можливостей; високим рівнем конфліктності; підвищеним рівнем агресивності, що виражається в афективних, розгальмованих формах відхилень в емоційно-вольовій сфері; низьким рівнем взаємодій з оточенням; низьким рівнем розвитку потреби в спілкуванні з навколишніми людьми; недосконалістю комунікативних засобів здійснення контактів.

Мотиваційний компонент комунікативної діяльності дітей із ЗПР характеризується одночасним проявом і позитивних, і негативних стосунків з однолітками, вони мають низьку соціально-комунікативну потребу; недостатне залучення у міжособистісні стосунки у колективі однолітків, занижене відчуття потреби в спілкуванні з однолітками, негативні установки для перспективної побудови комунікативної діяльності.

Психологічні особливості когнітивного компонента комунікативної діяльності виявляються у нездатності до диференційованої категоризації та оцінки значущих якостей людини; переважним типом категоризації є застосування недеференційованих суджень про якості іншої людини, коли пояснення однієї моральної якості здійснюється через іншу (труднощі на етапі категоризації насамперед пов'язані з недорозвитком мисленнєвої діяльності, пам'яті та уявлень); відсутність усвідомлення себе та усвідомлення іншої людини (що засвідчує низький рівень цінності іншої людини для дітей із ЗПР).

Емпіричним шляхом було виявлено рівні сформованості комунікативної діяльності учнів із ЗПР: перший рівень - низький, другий рівень - середній, третій рівень - достатній, четвертий рівень - високий (Мал.1).

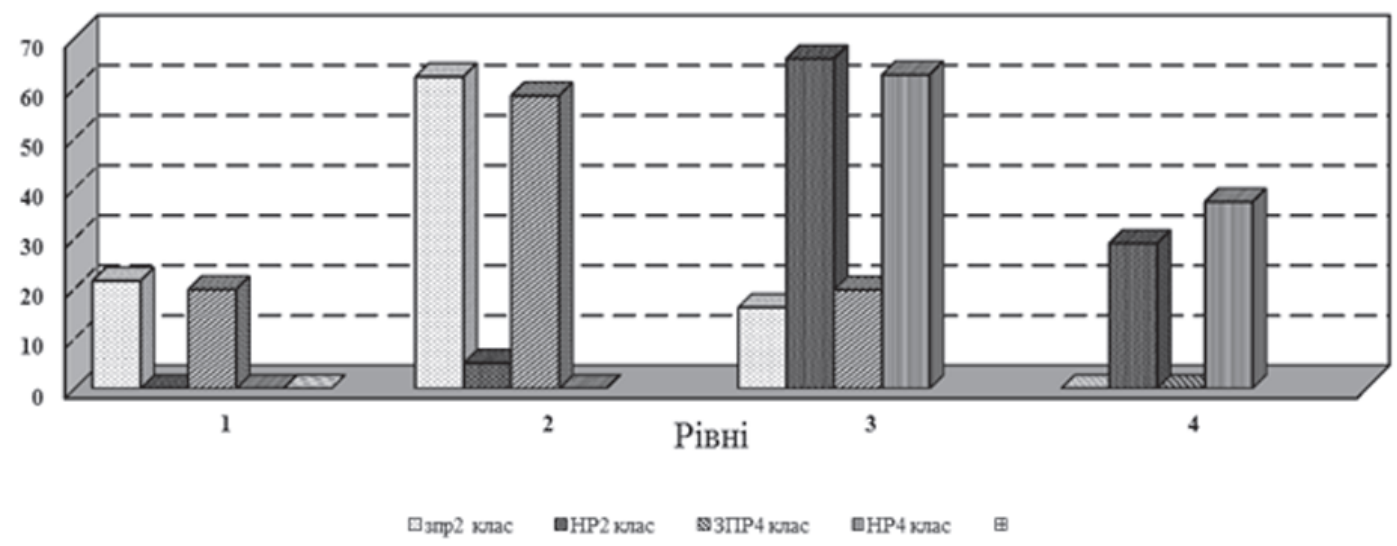

Мал. 1. Рівні сформованості компонентів комунікативної діяльності в учнів із ЗПР та НР 2-4-х класів (у \%)

Низъкий рівень сформованості компонентів комунікативної діяльності було виявлено у 21,5 \% учнів із ЗПР 2 класу та 19,8 \% - 4 класу (для порівнян-

«ОСОБЛИВА ДИТИНА: навчання і виховання», № 1, 2019 71 
ня - 0 \% учнів із НР 2-4 класів). Учні з низьким рівнем розвитку комунікативної діяльності мають низьку мотивацію на комунікацію як особистісного, так і соціального характеру, є комунікативно пасивними, комунікативні навички майже несформовані, у комунікативній взаємодії майже не дотримуються загальновизнаних правил спілкування. Вони мають значні труднощі у встановленні комунікативних зв'язків, погано розуміють співрозмовника, не є терпимими до висловлювань та зауважень оточуючих, що заважає виникненню міжособистісних стосунків. Такі підлітки мають проблеми, не відчувають емоційного стану співрозмовників, погано контролюють свою комунікативну поведінку, неє тактовні.

Середній рівень сформованості компонентів комунікативної діяльності було виявлено у 62,3 \% учнів 2 класу та $58,5 \%$ - 4 класу із ЗПР, для порівняння $5,1 \%$ учнів 2 класу та $0 \%$ - 4 класу із НР. Учні із середнім рівнем розвитку комунікативної діяльності залучаються в комунікативні контакти в основному після стимуляції з боку оточуючих, у комунікативній діяльності досить рідко виявляють комунікативну активність, комунікативні навички сформовані недостатньою мірою, їм достатньо складно вступати в комунікативні контакти, особливо розпочинати їх першими. Вони не завжди розуміють співрозмовника, свої емоції в комунікативній взаємодії їм складно контролювати, що негативно позначається на міжособистісних стосунках.

Достатній рівень сформованості компонентів комунікативної діяльності було виявлено у 16,2 \% учнів 2 класу та 21,7 \% - 4 класу із ЗПР, для порівняння - 65,9 \% учнів 2 класу та $62,7 \%$ - 4 класу із НР. Учні з достатнім рівнем комунікативної діяльності мають достатню мотивацію до комунікативної взаємодії як особистісного - так і соціального характеру, що визначається у достатній комунікативній активності. Такі діти мають розвинені комунікативні навички, достатньою мірою комунікабельні, що дає змогу їм установлювати комунікативні зв'язки з оточуючими. У комунікативній діяльності вони намагаються контролювати свої емоції, є толерантними до оточуючих та мають відповідно розвинені комунікативні здібності. У комунікативних контактах вони можуть контролювати свої емоції, що дає можливість мати гармонійні стосунки з оточуючими. У діалозі можуть виступати ініціаторами, можуть самі обирати теми для бесіди.

Високий рівень сформованості компонентів комунікативної діяльності не було виявлено в учнів 2 класу та 4 класу із ЗПР, для порівняння - 29 \% учнів 2 класу та 37,3 \% - 4 класу із НР. Діти з високим рівнем розвитку комунікативної діяльності мають мотивацію до комунікативної взаємодії як особистісного - так і соціального характеру, що визначається в достатній комунікативній активності. Такі учні мають розвинені комунікативні навички, достатньою мірою комунікабельні, що дає їм змогу встановлювати комунікативні зв'язки 3 оточуючими. У комунікативній діяльності вони вміють контролювати свої емоції, є толерантними до оточуючих та мають відповідно розвинені комунікативні здібності. У комунікативних контактах вони можуть контролювати свої емоції, що допомагає мати гармонійні стосунки з оточуючими. У діалозі часто є ініціаторами, можуть самі обирати теми для бесіди. 
Статистично встановлено взаємозв'язок між компонентами комунікативної діяльності в учнів із ЗПР і НР за допомогою лінійного кореляційного аналізу ( $r$-Пірсона). Значення «r» визначає ступінь взаємозв'язку між заданими показниками. Таке значення може змінюватися між «-1» до «+1». Чим ближче значення до «+1», тим вищий взаємозв'язок між заданими компонентами.

У пррцесі аналізу отриманих результатів було виявлено тісний вәясмпгв'язок між кпмпонентами комунікативної діяльності у дітей із НР - від $r=0,89$ до $r=0,95$. На відміну від них, у учнів із ЗПР вхағмпзв'язпк між комлпнентами комунікативної діяльності дуже слабкий (від $r=0,19$ до 0,25 ). При $p \leq 0,05$. Так, статистично встановлено високий взаємозв'язок між когніті
ваційним компонентом комунікативної діяльності в учнів із $\mathrm{HP}(r=0,95)$. Це вказує на існування залежності між вмінням категоризувати моральні якості, оцінювати значимі якості людини, яка визначає позитивне ставлення до іншої людини. На відміну від дітей із НР, їх однолітки із ЗПР показали значно нижчий показник взаємозв's $r=0 ;$ गгнітивним і операційним компонентом міжособистісних стосунків $(r=0,2 \mathbf{3})$. Це свідчить про те, що вміння взаємодіяти, встановлювати міжособистісні контакти в учнів із ЗПР визначаються низьким рівнем розвитку міжособистісних взаємодій.

Найнижчим в учнів із ЗПР виявився показник взаємозв'язку між мотиваційним і операційним компонентом комунікативної активності $(\mathrm{r}=0,19)$. Це свідчить про те, що для цих дітей достатньо складним завданням у процесі взаємодій є встановлення міжособистісного спілкування, міжособистісних контактів.

На відміну від учнів із ЗПР, їх однолітки із НР виявили високий взаємозв'язпк між мотиваційним і операційним компонентами міжособистісних стосунків $(r=0,91)$, що свідчить про достатньо високий рівень взаємодій між компонентами. Тобто, ці діти у процесі взаємодії встановлюють міжособистісні контакти, прагнуть до міжособистісного спілкування.

Так, низький рівень взаємодії, нездатність до оцінювання якостей людини, низька потреба в міжособистісному спілкуванні та встановленні міжособистісних контактів негативно впливають на формування комунікативної діяльності в учнів із ЗПР.

Аналіз значущості міжгрупових розбіжностей у дітей з нормальним психічним розвитком і дітей із ЗПР за $t$-критерієм Ст'юдента показав, що найбільш чіткі відмінності в діяльності дітей із ЗПР та дітей із НР виявляються на певних етапах комунікативної діяльності в процесі взаємодії. Виявлені відмінності між двома групами (зПр і НP) гтатистично значущі: соціальна спрямованість на ппнолікка $(t=4,3$ при $p \leq 0,05$ ), вирішення көнфліктних стлтацій $(t=5,12$ при $p \leq 0,05)$, тривалість взаємодій $(t=4,7$ при $p \leq 0,05)$.

Обговорення результатів дослідження. Теоретичною основою нашого теоретико-емпіричного дослідження стало положення про те, що опанування навичок комунікативної взаємодії учнів із ЗПР є необхідною умовою соціалізації і інтеграції в соціум (Д. Альраххаль, 1992; О. Асадулова, 2010; Z. Хin, 2004). У його підтвердження, наше дослідження засвідчило те, що у дітей із ЗПР недостатньо сформована комунікативна діяльність, на відміну від їх однолітків із

«ОСОБЛИВА ДИТИНА: навчання і виховання», № 1, 2019 73 
нормальним розвитком. Так, в учнів із ЗПР спілкування має швидкоплинний, поверхневий характер. Звя'зки з однолітками часто грунтуються не на принципах рівності, товариства, почуття обов'язку і відповідальності, а на примітивній залежності від більш зрілих і стенічних членів компаніїгрупи, на підлеглості. У складних, і тим більше, конфліктних ситуаціях ця група дітей часто реагує неадекватно, агресивно, грубо, роздратовано, проявляє негативізм та ігнорування суспільних норм.

Наше дослідження є доповненням для висновків Г. Онищенко, Л. Прохоренко, С. Хорунжого , про те, що низька мотивація на комунікацію як особистісного, так і соціального характеру, комунікативна пасивність, труднощі у встановленні комунікативних зв'язків, неконтрольованість своєї комунікативної поведінки призводить до низької сформованості комунікативної діяльності у дітей із ЗПР (Г. Онищенко, 2000; Л. Прохоренко, 2012; С. Хорунжий, 2000).

Варто зазначити, що проведений аналіз емпіричних даних засвідчив неготовність учнів із ЗПР до комунікативної взаємодії. Крім того, було встановлено, що зазначена категорія дітей має значні труднощі під час встановлення взаємодії один з одним. Наше дослідження є доповненням до емпіричного дослідження С. Тарасюк про те, що на комунікативну діяльність впливає рівень взаємодій з оточенням; рівень розвитку потреби в спілкуванні з навколишніми людьми; здійснення міжособистісних контактів (С. Тарасюк, 2001). Варто акцентувати, що діти із ЗПР характеризується одночасним проявом і позитивних, і негативних стосунків до однолітків, вони відчувають низьку соціально-комунікативну потребу, для них типова низка залученість комунікативну діяльність у колективі однолітків, занижене відчуття потреби в спілкуванні з однолітками, в побудові продуктивних міжособистісних стосунків, негативні установки для перспективної побудови продуктивних комунікативних взаємодій.

Висновки. Аналіз психологічної літератури засвідчив прогалини у вивченні комунікативної діяльності учнів із ЗПР. Це стало основою нашого емпіричного дослідження. Так, було встановлено, що у дітей із ЗПР комунікативна діяльність сформована недостатньо, низький стан сформованості компонентів комунікативної діяльності призводить до значних труднощів, що виникають під час взаємодії один з одним.

Отже, аналіз даних емпіричного дослідження дає підставу зробити висновок про неблагополуччя в особистісному розвитку і комунікативній діяльності учнів із ЗПР. Вони почувають себе незахищеними, мають емоційну тривогу і тому знаходяться у підвищеній залежності від оточення. Наявність глибокої своєрідності емоційно-вольового розвитку значною мірою визначає низький рівень сформованості комунікативної діяльності, будучи однією з причин малої соціальної активності й низького рівня соціальної адаптації дітей цієї категорії.

Такі висновки спонукають до вивчення шляхів корекційної роботи з формування компонентів комунікативної діяльності у учнів із ЗПР. 


\section{ЛITEPATУPA}

1. Бабяк О. О. Особливості афективного компонента міжособистісних стосунків у підлітків із ЗПР в шкільній групі / О. О. Бабяк // Актуальні питання корекційної освіти. - 2012. Вип. 3. - С. 282-290.

2. Еникеев М. И. Социальная психология / М. И. Еникеев. - М.: Приор, 2000. - 160 с.

3. Омельченко I. М. Простір комунікативної діяльності дошкільників із затримкою психічного розвитку: структура, чинники недорозвитку, умови формування / I. М. Омельченко // Збірник наукових праць Кам'янець-Подільського національного університету імені Івана Огієнка / за ред.

О. В. Гаврилова, В. І. Співака. - Вип. ХХ в двох частинах, частина 2. Серія: соціальнопедагогічна. - Кам'янець-Подільський : Медобори-2006, 2012. - С. 380-390.

4. Прохоренко Л. I. Особливості мотиваційного компоненту саморегуляції у молодших школярів із затримкою психічного розвитку в навчальній діяльності / Л. I. Прохоренко // Освіта осіб з особливими потребами: шляхи розбудови. -2012. - Вип. 3(1). --С. 129-133.

5. Петровский A. В. Социальная психология коллектива / А. В. Петровский, В. В. Шпалинский. М.: Просвещение, 1978. 176 с.

6. Ferguson C.J. The effectiveness of school-based anti-bullying programs: a meta-analytic review / C. J. Ferguson, C. San Miguel, J. C. Kilburn //Crim Justice Rev. - 2007. —32(4). - P. 401-414.

7. Xin Z. The Differences of Social Anxiety of Adolescents with Different Sociometric Status / Z. Xin, LChi, B. Liu // Chinese Mental Health Journal. -2004. - Vol 18(4). - 231-232.

\section{REFERENCES (TRANSLATED AND TRANSLITERATED)}

1. Babiak O.O. (2012). Osoblyvosti afektyvnoho komponenta mizhosobystisnykh stosunkiv u pidlitkiv iz ZPR v shkilnii hrupi / O. O. Babiak // Aktualni pytannia korektsiinoi osvity. -- Vyp. 3. -S. 282-290 [In Ukrainian].

2. Enikeev M. I. (2000). Sotsialnaia psikhologiia. Moscow [In Russian].

3. Omelchenko I. M. Prostir komunikatyvnoi diialnosti doshkilnykiv iz zatrymkoiu psykhichnoho rozvytku: struktura, chynnyky nedorozvytku, umovy formuvannia / I. M. Omelchenko // Zbirnyk naukovykh prats Kamianets-Podilskoho natsionalnoho universytetu imeni Ivana Ohiienka / za red. O. V. Havrylova, V. I. Spivaka. - Vyp. XX v dvokh chastynakh, chastyna 2. Seriia: sotsialno-pedahohichna. - Kamianets-Podilskyi : Medobory-2006, 2012. - S. 380-390 [In Ukrainian].

4. Prokhorenko L. I. (2012). Osoblyvosti motyvatsiinoho komponentu samorehuliatsii u molodshykh shkoliariv iz zatrymkoiu psykhichnoho rozvytku v navchalnii diialnosti / L. I. Prokhorenko // Osvita osib z osoblyvymy potrebamy: shliakhy rozbudovy. Vyp. 3(1). - S. 129133 [In Ukrainian].

5. Petrovskii A. V.(1978). Sotsialnaia psikhologiia kollektiva. Moscow: Prosveshchenie [In Russian].

6. Ferguson C.J. (2007). The effectiveness of school-based anti-bullying programs: a meta-analytic review. Crim Justice Rev. 32(4). - P. 401-414 [In English].

7. Xin Z. (2004). The Differences of Social Anxiety of Adolescents with Different Sociometric Status. Chinese Mental Health Journal. Vol 18(4). - 231-232 [In English]. 